\title{
Hepatitis C Virus from the Hearts of Patients with Myocarditis and Cardiomyopathy
}

\author{
Akira Matsumori, Chikao Yutani, Yoshihiko Ikeda, Sachio Kawai, and \\ Shigetake Sasayama
}

Department of Cardiovascular Medicine (AM, SS), Kyoto University, Kyoto; and Department of Pathology (CY, YI), National Cardiovascular Center, Osaka; and Department of Cardiology (SK), Juntendo University, Tokyo, Japan

SUMMARY: The myocardium may be the target of several types of viral infections. The importance of hepatitis C virus (HCV) infection has been recently noted in patients with myocarditis and in patients with dilated or hypertrophic cardiomyopathy. The present study sought to detect HCV genomes in formalin-fixed paraffin sections of autopsied hearts from patients with myocarditis and patients with dilated or hypertrophic cardiomyopathy. Paraffin sections were deparaffinized, RNA was extracted, and the positive and negative strands of HCV RNA were detected by performing reverse transcription and nested polymerase chain reaction. The polymerase chain reaction products were cloned and sequenced. $\beta$-actin gene was used as a control for the successful amplification of a housekeeping gene. Among 106 hearts examined, $\beta$-actin gene was amplified in 61 hearts (57.5\%). Among the latter, HCV RNA was detected in 13 hearts (21.3\%), and negative strands in 4 hearts (6.6\%). HCV RNA was found in 4 hearts $(33.3 \%)$ with myocarditis, in 3 hearts (11.5\%) with dilated cardiomyopathy, and in 6 hearts (26.0\%) with hypertrophic cardiomyopathy. The sequences recovered from nine patients were highly homologous to the standard strain of HCV. HCV genomes were not found in either 35 hearts from patients with myocardial infarction or 20 hearts from patients with noncardiac diseases. These HCV RNA positive samples were obtained from 1 heart in 1979, 7 hearts between 1980 and 1989 , and 5 hearts since 1990, indicating that HCV RNA can be amplified from paraffin-embedded hearts preserved for many years. This method of detecting HCV genomes in formalin-fixed paraffin cardiac specimens has enabled us to widen our research into HCV infection and has been helpful in identifying the presence of HCV infection in cardiac myopathic disorders. (Lab Invest 2000, 80:1137-1142).

$H$ epatitis $\mathrm{C}$ virus (HCV) has been associated with several extrahepatic manifestations, among which the best characterized are mixed cryoglobulinemia and glomerulonephritis, which appear to be related to small vessel vasculitis (Johnson et al, 1993). Some patients with long-standing cryoglobulinemia seem to be at risk for developing B cell non-Hodgkin's lymphoma. Porphyria cutanea tarda is also commonly associated with HCV infection. Other disorders in which the association is less firmly established include secondary Sjögren's syndrome, Moorhen's corneal ulcer, and hyper- and hypothyroidism. The pathogenesis of these extrahepatic complications is not well understood (Di Bisceglie, 1998).

The myocardium may be the target of several types of viral infections. Persistent enterovirus infection of the myocardium has been reported (Bowles et al, 1986; Kandolf et al, 1987), and the existence of a causative role of enteroviruses in acute myocarditis,

Received April 24, 2000

This work was supported in part by a grant for General Scientific Research from the Japanese Ministry of Education, Science, Sports, and Culture, by a Research Grant from the Japanese Ministry of Health and Welfare, and by a grant from Mitui Life Social Welfare Foundation.

Address reprint requests to: Dr. Akira Matsumori, Department of Cardiovascular Medicine, Kyoto University Graduate School of Medicine, 54 Kawahara-cho Shogoin, Sakyo-ku, Kyoto 606-8397, Japan; Fax: 8175 751 6477; E-mail:amat@kuhp.kyoto-u.ac.jp particularly in children, finds support in a metaanalysis. On the other hand, some of the studies examining the association of enteroviruses with dilated cardiomyopathy have been negative (Baboonian and Treasure, 1997). Etiologic roles for other viruses, particularly adenovirus (Martin et al, 1994; Towbin et al, 1994) and cytomegalovirus (Schonian et al, 1995) have also been reported.

The importance of $\mathrm{HCV}$ infection in patients with dilated and hypertrophic cardiomyopathy and myocarditis has been recently noted (Matsumori , 1997; Matsumori et al, 1995, 1996, 1998a, 1998b, 1999; Okabe et al, 1997). The present study was, therefore, designed to measure the prevalence of HCV infection in myocarditis and in hypertrophic and dilated cardiomyopathy, using formalin-fixed paraffin sections of autopsied hearts that had been collected over many years.

\section{Results}

Among 106 hearts with myocarditis and cardiomyopathy examined in this study, $\beta$-actin gene was amplified in 61 hearts $(57.5 \%)$ (Table 1$)$, confirming the feasibility of genomic analysis by polymerase chain reaction (PCR) of paraffin-embedded tissues stored for many years. The oldest specimen with a positive $\beta$-actin gene was from a heart autopsied in 1974 . Among 61 hearts with positive $\beta$-actin genes, HCV 
Table 1. Detection of $\beta$-Actin Gene and Hepatitis $\mathrm{C}$ Virus Genomes from the Autopsied Hearts of Patients with Myocarditis, and Dilated and Hypertrophic Cardiomyopathies

\begin{tabular}{|c|c|c|c|c|c|}
\hline \multirow[b]{2}{*}{ Diagnosis } & \multirow[b]{2}{*}{$n$} & \multicolumn{2}{|c|}{$\beta$-actin gene } & \multicolumn{2}{|c|}{$\begin{array}{c}\text { Hepatitis C virus } \\
\text { genomes/positive } \beta \text {-actin }\end{array}$} \\
\hline & & Positive, $n$ & Frequency, \% & Positive, $n$ & Frequency, \% \\
\hline Myocarditis & 14 & 12 & 85.7 & 4 & 33.3 \\
\hline Dilated cardiomyopathy & 50 & 26 & 52.0 & 3 & 11.5 \\
\hline Hypertrophic cardiomyopathy & 42 & 23 & 54.8 & 6 & 26.0 \\
\hline Total & 106 & 61 & 57.5 & 13 & 21.3 \\
\hline
\end{tabular}

RNA was detected in 13 hearts (21.3\%), positive strands were found in 11 hearts (18.0\%), and negative strands were seen in 4 hearts $(6.6 \%)$ (Table 1$)$.

HCV RNA was found in none of the patients with myocardial infarction or those with noncardiac diseases. The difference in frequency of presence of HCV RNA between patients with myocarditis/cardiomyopathy and myocardial infarction/noncardiac diseases was statistically significant: 13 of $106(12.3 \%)$ versus 0 of $55(0 \%), p=0.0047$.

HCV RNA was found in 4 of 12 hearts (33.3\%) with myocarditis and positive $\beta$-actin gene. HCV RNA was found in 3 hearts $(11.5 \%)$ with dilated cardiomyopathy, and in 6 hearts $(26.0 \%)$ with hypertrophic cardiomyopathy (Table 1; Fig. 1).

The prevalence of positive HCV RNA was higher in hearts of patients with myocarditis than in those with dilated cardiomyopathy, although the difference did not reach statistical significance $(p=0.18)$. Among 13 patients with positive $\mathrm{HCV}$, the oldest sample was obtained in 1979, 7 hearts were autopsied between 1980 and 1989, and 5 hearts were autopsied since 1990 (Table 2), confirming that HCV RNA can be

a

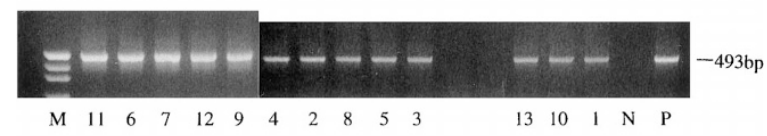

b

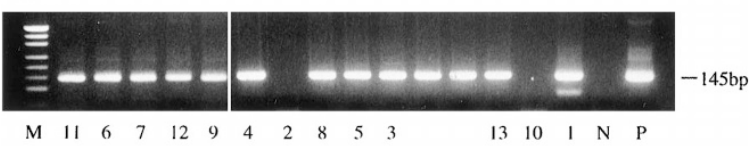

C

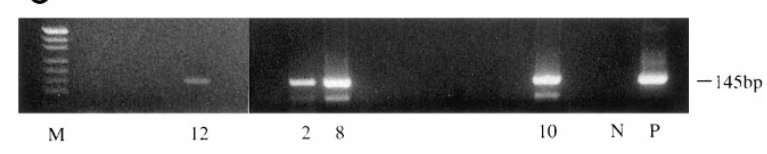

Figure 1.

Detection of $\beta$-actin gene (a), and positive (b), and negative strands (c) of hepatitis $C$ virus (HCV) RNA in the heart by strand-specific polymerase chain reaction (PCR) with primers from the HCV genomes. RNA was extracted from an autopsy specimen, reverse transcribed to complementary DNA, and amplified by nested PCR. The size of the expected amplification product was $493 \mathrm{bp}$ for $\beta$-actin and $145 \mathrm{bp}$ for HVC. Lane 1, DNA size marker (M); lane 17 , negative control $(\mathrm{N})$; lane 18 , positive control $(\mathrm{P})$; case numbers are shown below the lanes. amplified from paraffin-embedded cardiac specimens preserved for several years.

Of the 13 HCV-positive samples, 4 could not be sequenced because of nonspecific reactions. Figure 2 shows the results of sequences of $9 \mathrm{HCV}$-positive samples. Compared with the HPCJ483 strain, the sequence of Case no. 12 was identical, whereas the sequences of the other 8 cases were different in 1 to 7 bases. Therefore, the sequences of these 9 clones recovered from the hearts of patients showed more than $93 \%$ homology to the strain HPCJ483.

Among these 106 patients, 6 had been tested for the presence of anti-HCV antibody. Anti-HCV antibody was detected in 1 patient in whom HCV genomes were not present in the heart.

\section{Discussion}

$\mathrm{HCV}$, an RNA virus identified in 1989 (Choo et al, 1989; Kuo et al, 1989), is a major cause of both transfusionassociated and sporadic non- $A$, non- $B$ hepatitis. A prominent characteristic of hepatitis $C$ is the risk of persistent infection and progression to chronic liver disease. Persistent infection occurs in more than 50\% of patients infected with $\mathrm{HCV}$ and may result in chronic active hepatitis, cirrhosis, and possibly, hepatocellular carcinoma (Alter, 1991).

Over a 7-year period, we found antibody against $\mathrm{HCV}$ in 6 of 36 patients (16.7\%) with dilated cardiomyopathy, versus 1 of 40 patients $(2.5 \%)$ with ischemic heart disease, a statistically significant difference (Matsumori et al, 1995). HCV RNA was found in the autopsied hearts of 1 patient, and in the biopsy specimens of 2 patients. Negative strands of HCV RNA were detected in the heart of 1 patient. HCV infection was also commonly found in patients with hypertrophic cardiomyopathy, with HCV RNA detected in the hearts of 4 out of 6 patients with HCV antibody (Matsumori et al, 1996). It is noteworthy that, in 2 of these patients, HCV RNA was not detectable in the serum. One patient who suffered from acute hepatitis and myocarditis contemporaneously later developed ventricular hypertrophy, suggesting that HCV infection caused both acute myocarditis and the subsequent development of hypertrophic cardiomyopathy (Matsumori et al, 1996). More recently, we found a high frequency of HCV RNA in the hearts of patients with the apical type of hypertrophic cardiomyopathy (Matsumori et al, 1998b, 1999). 
Table 2. Patient Information and Date of Autopsy for Patients with Positive Hepatitis C Virus Genomes

\begin{tabular}{|c|c|c|c|c|c|c|}
\hline \multirow[b]{2}{*}{$\begin{array}{l}\text { Case } \\
\text { No. }\end{array}$} & \multirow[b]{2}{*}{ Age/Sex } & \multirow[b]{2}{*}{ Diagnosis } & \multirow[b]{2}{*}{$\begin{array}{l}\text { Date of } \\
\text { autopsy }\end{array}$} & \multicolumn{2}{|c|}{ Virus genomes } & \multirow[b]{2}{*}{$\beta$-actin } \\
\hline & & & & $\begin{array}{l}\text { Positive } \\
\text { strands }\end{array}$ & $\begin{array}{l}\text { Negative } \\
\text { strands }\end{array}$ & \\
\hline 1 K.K. & $54 / \mathrm{M}$ & Dilated cardiomyopathy & 1979 & + & - & + \\
\hline 2 Y.K. & $18 / F$ & Myocarditis & 1980 & - & + & + \\
\hline 3 K.Y. & $63 / F$ & Myocarditis & 1983 & + & - & + \\
\hline 4 Y.I. & $36 / F$ & Dilated cardiomyopathy & 1983 & + & - & + \\
\hline $5 \mathrm{I} . \mathrm{S}$. & $57 / F$ & Myocarditis & 1983 & + & - & + \\
\hline 6 T.M. & $27 / M$ & Hypertrophic cardiomyopathy & 1984 & + & - & + \\
\hline 7 K.T. & $61 / \mathrm{M}$ & Hypertrophic cardiomyopathy & 1989 & + & - & + \\
\hline 8 T.S. & $66 / F$ & Hypertrophic cardiomyopathy & 1989 & + & + & + \\
\hline 9 T.0. & $61 / \mathrm{M}$ & Hypertrophic cardiomyopathy & 1992 & + & - & + \\
\hline 10 C.S. & $67 / F$ & Myocarditis & 1993 & - & + & + \\
\hline 11 K.T. & $78 / \mathrm{M}$ & Hypertrophic cardiomyopathy & 1993 & + & - & + \\
\hline 12 E.F. & $45 / F$ & Dilated cardiomyopathy & 1994 & + & + & + \\
\hline 13 K.K. & $61 / \mathrm{M}$ & Hypertrophic cardiomyopathy & 1997 & + & - & + \\
\hline
\end{tabular}

[71]

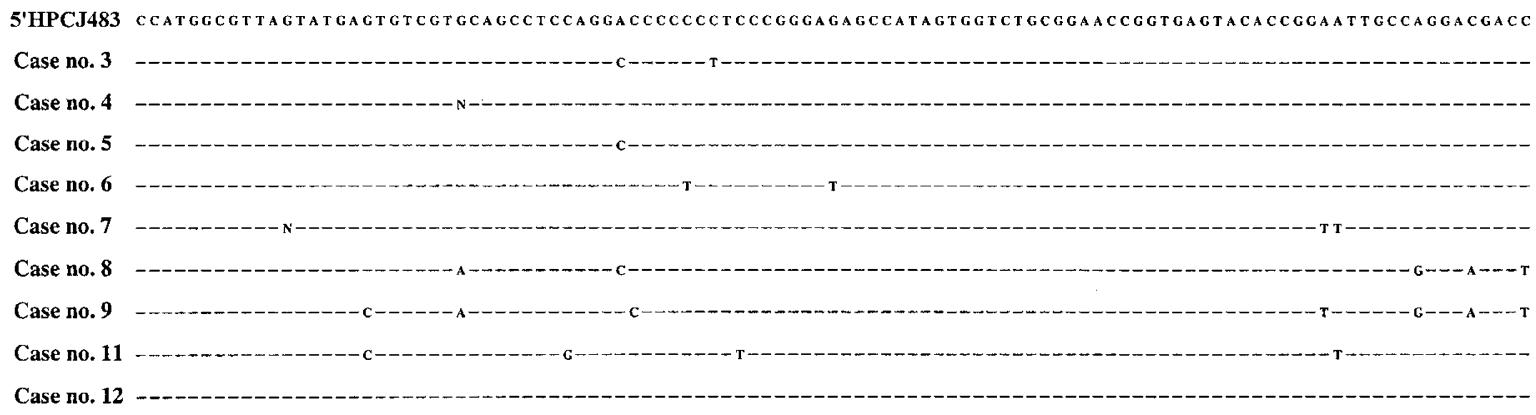

\section{Figure 2.}

The $5^{\prime}$ noncoding region nucleotide sequences of HCV and the clones recovered from the 9 patients with cardiomyopathy and myocarditis. Horizontal bars indicate nucleotides identical to those of the published sequence of the strain. The sequences were highly homologous to the standard strain of HPCJ483.

In a collaborative research project of the Committees for the Study of Idiopathic Cardiomyopathy, a questionnaire was recently submitted to participating Japanese medical centers with a view to identifying a possible association between HCV infection and cardiomyopathies. HCV antibody was found in 74 of 697 patients (10.6\%) with hypertrophic cardiomyopathy and in 42 of 663 patients (6.3\%) with dilated cardiomyopathy, prevalences significantly higher than those measured among Japanese volunteer blood donors (Matsumori et al, 1998a). The presence of HCV antibody was detected in 650 of 11,967 patients $(5.4 \%)$ seeking care in five academic hospitals. Various cardiac abnormalities were found among these anti-HCV antibody-positive patients, with arrhythmias the most frequent. These observations suggest that HCV infection is an important cause of a variety of otherwise unexplained heart diseases.

Okabe et al (1997) have reported the recovery of positive and negative strands of HCV RNA in paraffinembedded cardiac tissue blocks from patients with chronic active myocarditis . Although degradation of RNA is a problem in paraffin-embedded tissues for genomic analysis (Bresters et al, 1994; Lo et al, 1989),
HCV RNA could be amplified in the specimens examined in that study. In the present study, a heart autopsied in 1979 was positive for both $\beta$-actin gene and HCV RNA, indicating that HCV genomes are preserved for at least 19 years and that HCV RNA can be detected in tissue specimens preserved for many years. In addition to positive strands of HCV genomes, negative strands were also detected in 4 hearts, suggesting that HCV replicates in myocardial tissue. To confirm that the recovered sequence was derived from $\mathrm{HCV}$, we used sequence analysis of the genomes recovered in heart samples obtained from patients with cardiomyopathy and myocarditis. Of nine sequences recovered from patients, one clone was identical with the standard strain of $\mathrm{HCV}$, and the other eight clones were highly homologous to it, confirming that these clones were derived from HCV genomes. These results confirm the suitability of the method to detect HCV genomes from formalin-fixed paraffin specimens, and they lend support to the perceived important role played by HCV infection in the pathogenesis of myocarditis and dilated or hypertrophic cardiomyopathy. 
Familial hypertrophic cardiomyopathy has been reported to be caused by mutations in the genes for $\beta$-cardiac myosin heavy chain (Geisterfer-Lowrance et al, 1990), $\alpha$-tropomyosin, and cardiac troponin T (Watkins et al, 1995). However, in more than $50 \%$ of cases of familial hypertrophic cardiomyopathy and in most cases of nonfamilial hypertrophic cardiomyopathy, the etiology remains unknown. In the present study, HCV RNA was found in the hearts of 3 of 11 patients with familial hypertrophic cardiomyopathy.

Formalin-fixed, paraffin-embedded tissues have been used to detect genomes of adenovirus, cytomegalovirus, and enterovirus (Lozinski et al, 1994; Martin et al, 1994). This method of detecting hepatitis $C$ virus genomes from formalin-fixed paraffin cardiac specimens has enabled us to widen our research into HCV infection using biopsy or autopsy specimens, and it has been helpful in identifying the presence of $\mathrm{HCV}$ infection in cardiac myopathic disorders.

Hepatitis $C$ is now the major cause of liver disease requiring transplantation among adults in most countries. In the United States, the Centers for Disease Control and Prevention have estimated that hepatitis $C$ is responsible for 8,000 to 10,000 deaths annually. Furthermore, deaths from hepatitis $\mathrm{C}$ are expected to more than triple over the next 2 decades, eventually resulting in a higher mortality than AIDS (National Institutes of Health Consensus Development Conference Panel statement, 1997). Therefore, further studies of the relationship between hepatitis $C$ virus infection and cardiomyopathy or myocarditis are warranted.

\section{Materials and Methods}

The study population consisted of 14 patients with myocarditis, 50 patients with dilated cardiomyopathy, and 42 patients with hypertrophic cardiomyopathy, who had been autopsied between 1979 and 1997. There were 71 men and 35 women, 14 to 82 years of age $($ mean $=49.9 \pm 18.7$ years). A familial occurrence was noted in 5 patients with dilated cardiomyopathy and in 11 patients with hypertrophic cardiomyopathy. The pathological diagnoses were made as described previously (Katsuragi et al, 1993; Kawai et al, 1987; Kawai and Okada, 1990; Okada et al, 1989; Yutani et al, 1985, 1987).

The hearts from 35 patients with myocardial infarction, 43 to 92 years of age (mean $=72.8 \pm 10.7$ years), and 20 patients with noncardiac diseases (pulmonary and systemic arterial diseases, $n=9$; cerebrovascular disease, $n=11), 24$ to 87 years of age (mean $=63.7 \pm$ 17.7 years), were studied as controls. The hearts were fixed in buffered $10 \%$ formalin and embedded in paraffin. Sections from the left ventricle were cut into $6 \mu \mathrm{m}$-thick slices. Paraffin sections were deparaffinized in $1 \mathrm{ml}$ of xylene and centrifuged at 5,000 rpm for 5 minutes. Pellets were washed twice in 100\% ethanol and RNA was extracted using guanidinium thiocyanate/phenol/chloroform/isoamylalcohol.

The positive and negative strands of viral RNA were detected by performing reverse transcription of RNA samples in the presence of a single oligonucleotide primer (either the sense or the antisense primer), followed by heat inactivation of the reverse transcriptase. The DNA produced in this reverse transcription reaction was therefore complementary to one of the two RNA strands and could then be amplified by PCR in the presence of both oligonucleotide primers.

The oligonucleotide primers used were chosen from the highly conserved $5^{\prime}$ noncoding region nucleotide sequence of the HCV genome. For the external primers, the following sequences were used: sense, nucleotide Nos. 26 to 50, 5'-CACTCCCCTGTGAGGAACTACTGTC-3', and antisense, nucleotide Nos. 307 to 331 , 5'-ATGGTGCACGGTCTACGAGACCTCC-3'. The internal primers were as follows: sense, nucleotide Nos. 51 to 70, 5'-TTCACGCAGAAAGCGTCTAG-3', and antisense, nucleotide Nos. 176 to $195,5^{\prime}$ GTTGATCCAAGAAAGGACCC-3'.

Reverse transcription (RT) was performed as described in a $20-\mu$ l reaction volume containing $1 \mu \mathrm{l}$ of RNA, $0.4 \mathrm{~mm}$ of either the sense or antisense outer primer, $250 \mu \mathrm{M}$ of the four dNTP (Perkin Elmer Cetus, Norwalk, Connecticut), $15 \mathrm{U}$ of RNasin (Wako Chemical, Co., Ltd., Osaka, Japan), $1 \times$ RT buffer and $100 \mathrm{U}$ of murine leukemia reverse transcriptase (Gibco BRL, Eggenstein, Germany). The mixture was incubated at $37^{\circ} \mathrm{C}$ for 1 hour. RT was then inactivated by heating at $95^{\circ} \mathrm{C}$ for 30 minutes, and the mixture was quickly chilled on ice.

PCR amplification was performed by adding $77.5 \mathrm{ml}$ of $1 \times$ PCR buffer containing $400 \mu \mathrm{M}$ of the opposite sense or antisense primer and $2.5 \mathrm{U}$ of Taq polymerase (Perkin Elmer Cetus). Mineral oil was poured on top of the mixture. The thermocycler was programmed to incubate samples for single cycles at $92^{\circ} \mathrm{C}$ for 5 minutes, $55^{\circ} \mathrm{C}$ for 2 minutes, and $72^{\circ} \mathrm{C}$ for 3 minutes, followed by 35 cycles at $90^{\circ} \mathrm{C}$ for 1 minute, $55^{\circ} \mathrm{C}$ for 1 minute, and $72^{\circ} \mathrm{C}$ for 2 minutes, followed by a final 10 minutes at $72^{\circ} \mathrm{C}$.

For the second amplification, $5 \mu \mathrm{l}$ removed from the first reaction was added to a reaction mixture similar to the first mixture, however, with $1 \mu \mathrm{M}$ of the inner instead of the outer primers. PCR was carried out for 35 cycles as described for the first amplification. Ten microliters of the second amplification was analyzed by electrophoresis in a $3 \%$ agarose gel containing 1 $\mu \mathrm{g} / \mathrm{ml}$ of ethidium bromide and visualized under ultraviolet light. The size of the expected amplification product was $145 \mathrm{bp}$.

PCR products were purified with Sephaglas Band Prep (Pharmacia Biotech, Uppsala, Sweden). Dideoxy DNA sequencing was performed by the dye termination method in an $\mathrm{ABI}$ automated DNA sequencer (Applied Biosystems, Foster City, California) with the BigDye Terminator Cycle Sequence Ready Reaction (Applied Biosystems) as specified by the manufacturers. HCV 5' HPCJ 483 was used as a standard strain of the virus (Okamoto et al, 1992).

$\beta$-actin gene was used as control for the successful amplification of a housekeeping gene. The sequences of the oligonucleotides were as follows: sense, 5'GTGGGGCGCCCCAGGCACCA-3', and antisense, 5' GATCCTCACCGAGCGCGGCTACA-3'. RT-PCR was performed with a selective RNA PCR kit (Takara 
Shuzo, Co., Ltd., Kyoto, Japan), according to the manufacturer's protocols. The amplification reactions for $\beta$-actin consisted of 40 cycles at $85^{\circ} \mathrm{C}$ for 1 minute, annealing at $58^{\circ} \mathrm{C}$ for 1 minute, and extension at $72^{\circ} \mathrm{C}$ for 1 minute. The size of the expected amplification product was $493 \mathrm{bp}$.

Differences between groups in the frequency of HCV genomes were tested by Fisher's exact test. A p value $<0.05$ was considered significant.

\section{Acknowledgements}

We thank Mr. T. Hadama, Mr. T. Miura, Mr. M. Tomioka, and Mr. H. Toriyama for their help in the establishment of the method for detecting hepatitis $C$ virus genomes, and Ms. S. Sakai and Ms. Y. Okazaki for preparing the manuscript.

\section{References}

Alter HJ (1991). Descartes before the horse: I clone, therefore I am: The hepatitis $C$ virus in current perspective. Ann Intern Med 115:644-649.

Baboonian C and Treasure T (1997). Meta-analysis of the association of enteroviruses with human heart disease. Heart 78:539-543.

Bowles NE, Richardson PJ, Olsen EG, and Archard LC (1986). Detection of Coxsackie-B-virus-specific RNA sequences in myocardial biopsy samples from patients with myocarditis and dilated cardiomyopathy. Lancet 1:11201123.

Bresters D, Schipper ME, Reesink HW, Boeser-Nunnink BD, and Cuypers HT (1994). The duration of fixation influences the yield of HCV cDNA-PCR products from formalin-fixed, paraffin-embedded liver tissue. J Virol Methods 48:267-272.

Choo QL, Kuo G, Weiner AJ, Overby LR, Bradley DW, and Houghton M (1989). Isolation of a cDNA clone derived from a blood-borne non-A, non-B viral hepatitis genome. Science 244:359-362.

Di Bisceglie AM (1998). Hepatitis C. Lancet 351:351-355.

Geisterfer-Lowrance AA, Kass S, Tanigawa G, Vosberg HP, McKenna W, Seidman CE and Seidman JG (1990). A molecular basis for familial hypertrophic cardiomyopathy: A beta cardiac myosin heavy chain gene missense mutation. Cell 62:999-1006.

Johnson RJ, Gretch DR, Yamabe H, Hart J, Bacchi CE, Hartwell P, Couser WG, Corey L, Wener MH, Alpers CE, and Willson R (1993). Membranoproliferative glomerulonephritis associated with hepatitis $\mathrm{C}$ virus infection. $\mathrm{N}$ Engl $\mathrm{J}$ Med 328:465-470.

Kandolf R, Ameis D, Kirschner P, Canu A, and Hofschnieder $\mathrm{PH}$ (1987). In situ detection of enteroviral genomes in myocardial cells by nucleic acid hybridization: An approach to the diagnosis of viral heart disease. Proc Natl Acad Sci USA 84:6272-6276.

Katsuragi M, Yutani C, Imakita M, Ishibashi-Ueda $H$, and Fujita $H$ (1993). Cell infiltration caused deterioration in the prognosis of patients with clinical diagnosis of dilated cardiomyopathy (DCM): Application of biopsy criteria of myocarditis to 42 autopsy cases. Heart Vessels 8:42-47.
Kawai S, Shimizu M, Okada R, and Ih S (1987). A morphological analysis of chronic myocarditis. Jpn Circ J 51:13851392.

Kawai S and Okada R (1990). Interstitial cell infiltrate and myocardial fibrosis in dilated cardiomyopathy: A special type of cardiomegaly corresponding to sequelae of myocarditis. Heart Vessels 5:230-236.

Kuo G, Choo QL, Alter HJ, Gitnick GL, Redeker AG, Purcell $\mathrm{RH}$, Miyamura T, Dienstag JL, Alter MJ, Stevens CE, Tegtmeier GE, Bonino F, Colombo M, Lee WS, Kuo C, Berger K, Shuster JR, Overby LR, Bradley DW, and Houghton M (1989). An assay for circulating antibodies to a major etiologic virus of human non-A, non-B hepatitis. Science 244:362-364.

Lo YM, Mehal WZ, and Fleming KA (1989). In vitro amplification of hepatitis $B$ virus sequences from liver tumour DNA and from paraffin wax embedded tissues using the polymerase chain reaction. J Clin Pathol 42:840-846.

Lozinski GM, Davis GG, Krous HF, Billman GF, Shimizu H, and Burns JC (1994). Adenovirus myocarditis: Retrospective diagnosis by gene amplification from formalin-fixed, paraffinembedded tissues. Hum Pathol 25:831-834.

Martin AB, Webber S, Fricker FJ, Jaffe R, Demmler G, Kearney D, Zhang Y-H, Bodurtha J, Gelb B, Ni J, Bricker T, and Towbin JA (1994). Acute myocarditis: Rapid diagnosis by PCR in children. Circulation 90:330-333.

Matsumori A, Matoba Y, and Sasayama S (1995). Dilated cardiomyopathy associated with hepatitis $\mathrm{C}$ virus infection. Circulation 92:2519-2525.

Matsumori A, Matoba $\mathrm{Y}$, Nishio R, Shioi T, Ono K, and Sasayama S (1996). Detection of hepatitis C virus RNA from the heart of patients with hypertrophic cardiomyopathy. Biochem Biophys Res Commun 222:678-682.

Matsumori A (1997). Molecular and immune mechanisms in the pathogenesis of cardiomyopathy: Role of viruses, cytokines, and nitric oxide. Jpn Circ J 61:275-291.

Matsumori A, Ohashi N, Hasegawa K, Sasayama S, Eto T, Imaizumi T, Izumi T, Kawamura K, Kawana M, Kimura A, Kitabatake A, Matsuzaki M, Nagai R, Tanaka H, Hiroe M, Hori M, Inoko H, Seko Y, Sekiguchi M, Shimotohno K, Sugishita Y, Takeda N, Takihara K, Tanaka M, Tokuhisa T, Toyo-oka T, and Yokoyama M (1998a). Hepatitis C virus infection and heart diseases: A multicenter study in Japan. Jpn Circ $J$ 62:389-391.

Matsumori A, Ohashi N, and Sasayama S. (1998b). Hepatitis C virus infection and hypertrophic cardiomyopathy. Ann Intern Med 129:749-750.

Matsumori A, Ohashi N, Nishio R, Kakio T, Hara M, Furukawa Y, Ono K, Shioi T, Hasegawa K, and Sasayama S (1999). Apical hypertrophic cardiomyopathy and hepatitis $\mathrm{C}$ virus infection. Jpn Circ J 63:433-438.

National Institutes of Health (1997). Management of hepatitis C (NIH Consensus Development Conference Panel Statement). Hepatology 26:2s-10s.

Okabe M, Fukuda K, Arakawa K, and Kikuchi M (1997). Chronic variant of myocarditis associated with hepatitis $C$ virus infection. Circulation 96:22-24.

Okada R, Kawai S, and Kasyuya H (1989). Nonspecific myocarditis: A statistical and clinicopathological study of autopsy cases. Jpn Circ J 53:40-48. 
Okamoto H, Kojima M, Okada S, Yoshizawa H, lizuka $H$, Tanaka T, Muchmore EE, Peterson DA, Ito Y, and Mishiro S (1992). Genetic drift of hepatitis C virus during an 8.2 year infection in a chimpanzee: Variability and stability. Virology 190:894-899.

Schonian U, Crombach M, Maser S, and Maisch B (1995). Cytomegalovirus-associated heart muscle disease. Eur Heart J 16(Suppl O):46-49.

Towbin JA, Griffin LD, Martin AB, Nelson S, Siu B, Ayres NA, Demmler G, Moise KJ Jr and Zhang YH (1994). Intrauterine adenoviral myocarditis presenting as nonimmune hydrops fetalis: diagnosis by polymerase chain reaction. Pediatr Infect Dis J 13:144-150.
Watkins H, McKenna WJ, Thierfelder L, Suk HJ, Anan R, O'Donoghue A, Spirito P, Matsumori A, Moravec CS, Seidman JG, and Seidman CE (1995). Mutations in the genes for cardiac troponin $\mathrm{T}$ and alpha-tropomyosin in hypertrophic cardiomyopathy. N Engl J Med 332:1058-1064.

Yutani C, Imakita M, Ishibashi-Ueda H, Hatanaka K, Nagata S, Sakakibara H, and Nimura Y (1985). Three autopsy cases of progression to left ventricular dilatation in patients with hypertrophic cardiomyopathy. Am Heart J 109:545-553.

Yutani C, Imakita M, Ishibashi-Ueda H, Nagata S, Sakakibara $\mathrm{H}$, and Nimura $\mathrm{Y}$ (1987). Histopathological study of hypertrophic cardiomyopathy with progression to left ventricular dilatation. Acta Pathol Jpn 37:1041-1052. 